\title{
相互排他性原理に基づくマルチモーダル共同注意
}

中 野 吏 $* 1 * 2$ 吉川雄一郎*2 浅 田 稔 $* 1 * 2$ 石 黒 浩*1*2

\section{Multimodal Joint Attention Based on Mutual Exclusivity Principle}

\author{
Tsukasa Nakano*1*2, Yuichiro Yoshikawa*2, Minoru Asada*1*2 and Hiroshi Ishiguro*1*2
}

\begin{abstract}
In this paper, we propose a method for simultaneous learning of multi-modules for joint attention: gaze-driven attention and word-driven attention. Inspired from child language acquisition, mutually exclusivity bias is utilized for mutual facilitative learning both in an intra- and inter-module manner by extending a modified Hebbian learning rule. Experiments on a human-robot interaction and on the computer simulations, we analyzed that the proposed method enabled mutually facilitative learning of a mapping for gaze-following and a label-to-object mapping by which the learner performs multimodal joint attention with its caregiver. Finally, through a computer simulation resembling mother-infant interaction, we argued a possibility of the proposed learning mechanism as a constructivist model for infant's cognitive development.
\end{abstract}

Key Words: Joint Attention, Mutual Exclusivity, Simultaneous Learning of Multi-functions

\section{1.は じめに}

他者とコミュニケーションを行う際には，他者と共同注意を することが重要である。共同注意とは他者と同一の対象物に注 意を向ける行動であり, 複数のモダリティの情報（視線, 言葉, 指差し等）を手がかりに達成することができる，発達心理学の 研究では, 人の幼児は共同注意に必要な視線追従能力 [1] や語 彙 [2] を 12〜18ケ月頃の同時期に獲得しているとされている. これらの能力の発達過程は相互に促進するものであることが伺 える [3] [4] が, このような複数の機能の相互促進を支える学習 メカニズムについては明らかではない.

これに対し，発達するロボットを構築することを通じて幼児 の発達メカニズムの新たな理解を目指す, 構成論的アプローチ が注目を集めている [5]. 構成論的アプローチの従来研究として, 共同注意の機能である視線追従 [6] [7] や語彙 [8]〜 [10] のマッピ ングをロボットやエージェントに学習させる研究がある。しか し, これらの研究ではいずれかのモダリティの学習に焦点があ てられており，マルチモーダルな共同注意の機能の相互促進的 学習は考慮されていなかった。一方, Yu ら [11] は複数の物体 が存在する状況で, 教示者の視線情報を利用することで効率的 に語彙マッピングが学習できることを示したが, 視線を追従す る機能は設計者によりあらかじめ与えられていた。 マルチモー

原稿受付 2009 年 1 月 9 日

$* 1$ 大阪大学大学院工学研究科

*2 JST ERATO 浅田共創知能プロジェクト

${ }^{* 1}$ Graduate School of Engineering, Osaka University

${ }^{* 2}$ Asada Synergistic Intelligence Project, ERATO, JST

口本論文は学術性で評価されました。
ダルな共同注意の複数機能を同時学習させることを考えた場合, はじめから，それぞれの機能が他方の学習を促進することは期 待できず, どのようにそれぞれの機能の学習を進め, 統合させ れば相互促進が可能であるかを考える必要がある。

そこで本研究ではマルチモーダルな共同注意による語彙およ び視線追従能力のマッピングの同時学習を実現する相互促進的 学習が可能な学習メカニズムを提案し, 幼肾の共同注意発達過 程の構成論的理解を図る. 幼児の初期の語彙学習過程では, 物 体とラベルが相互排他的に対応づけられるバイアスがあること が知られ，相互排他性バイアスと呼ばれている [12]. ここで，二 つのものが相互排他的に対応付けられている, とは双方が他方 に対して一意的に対応すると捉えられていることを指し, 幼児 が初めて聞く物体の名称をすでに他の名称が与えられた物体へ は結びつけないことはこのようなバイアスによるものであると 考えられている。これは乳児の初期のマッピング学習において, モダリテイを問わず，既知の対応関係に照らし合わせてどの経 験が学習に用いられるべきかが取捨選択される結果, 効率的な 1 対 1 マッピングの構築に利用されている可能性を示唆してい る. そこで本研究では, このような相互排他性バイアスに基づ く学習メカニズムを語彙と視線追従の両方のマッピング学習に 適用することで, 各モダリティの 1 対 1 マッピングの学習を効 率化すると同時に，モダリティを跨いだ相互促進の実現を図る。 具体的には, 自身と結合先のノードの排他性を考慮してノード 間の対応を学習する交差投錨型ヘッブ則 [13] を語彙と視線追従 の両方のマッピング学習に応用する。これによりノード間の結 合強度として個々のマッピングの相互排他性が明示的に表現さ れることとなり, 各モダリティの出力を相互排他性に応じて統 
合することができる結果として，相互促進学習を実現する.

本稿では 2 章でマルチモーダルな共同注意における視線追従 および語彙の同時学習のための相互排他性原理の実装方法につ いて説明する。 3 章では比較的簡単な環境で実施した実ロボッ トと人の共同注意学習実験において提案手法の有効性を検証し たあと,より複雑な環境を設定した計算機シミュレーションを 行い, 提案手法によりどのように各モジュールが相互促進可能 であるかを検証する。最後に親子インタラクションを模した状 況での計算機シミュレーション結果を示し, 幼児の発達過程と の相同性および今後の課題について議論する.

\section{2. 相互排他性原理に基づく共同注意}

本研究で想定する学習者と養育者のインタラクションの状況 を Fig. 1 に示す。養育者は周囲に配置された複数の物体の中か ら一つを選択し, これを見ながら, その名称 (以下ラベル) を発 話する．学習者のタスクはこのような養育者の振る舞いを手が かりに，試行錯誤を通じて養育者と同じものを見ること，すな わち, 共同注意を獲得することである. Fig. 2 に本研究で用い る学習者の共同注意学習システムを示す。共同注意の実現のた め, 学習者は以下で詳述する視線による注意モジュール (Fig. 2 上部）と言葉による注意モジュール (Fig. 2 下部) の出力を統合 して注視方向を決定し, その結果である物体への注視経験をも とに, これらのモジュールのパラメータを更新する。この試行 錯誤を通じて, 学習者は養育者の視線とその視線の先の位置の

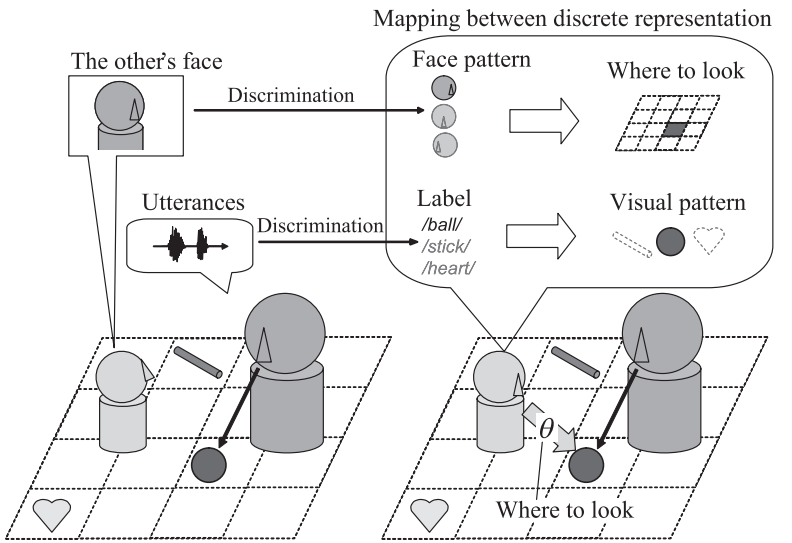

Fig. 1 Setting for learning multimodal joint attention

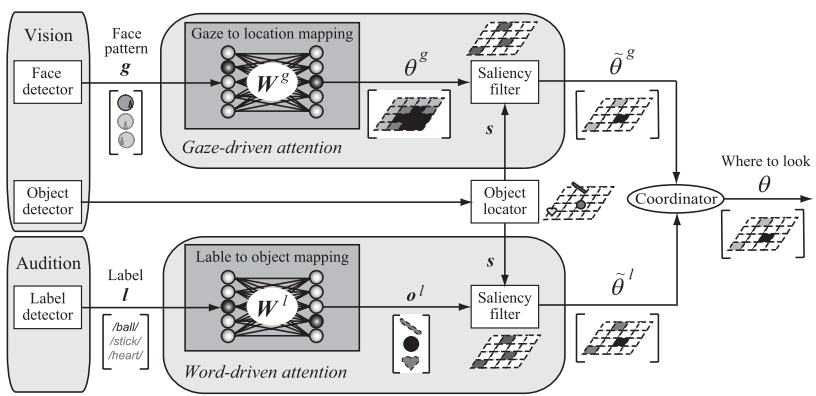

Fig. 2 Learning mechanism of joint attention with two modules: gaze-driven attentional one (top) and word-driven attentional one (bottom)
マッピングと, ラベルとラベルが指す物体のマッピングを学習 する. ただし, 共同注意が成功したか否かの直接的な情報（教示 や強化信号) は学習者に与えられていないことに注意されたい.

以下では, 環境は $N$ 個に分割されているとし, 一つのスポッ トに置かれる物体は最大一つであるとする。また環境に配置さ れる物体の候補は $M$ 個あり, 一度に置かれる物体の数は $M_{o}$ であるとする，どの物体がどこに配置されるかは，T ステップ ごとにランダムに決定しなおされる。ここで 1 ステップとは, 教示者が一つの物体を注視し, そのラベルを発話してから, 口 ボットがこれらの情報をもとに注視対象を決定し, 視線追従と 語彙のマッピングを更新するまでの間を指す.

\section{1 視線による注意モジュール}

視線による注意モジュールは，養育者が物体を注視している 様子, すなわち顔についての観測情報を表す $G$ 次元べクトル $\boldsymbol{g}$ を入力として，共同注意のために注視されるべき位置を

$$
\boldsymbol{\theta}^{g}=\boldsymbol{W}^{g} \boldsymbol{g}
$$

のように出力する.ここで， $\boldsymbol{\theta}^{g}$ は，養育者の視線を手がかりと したときに環境中の各スポットが注視されるべき程度を要素と する $N$ 次元ベクトルである。 また $\boldsymbol{W}^{g}$ はマッピングの結合荷 重であり， $N \times G$ 行列である，本論文の実験では， $\boldsymbol{g}$ を観測 された養育者の顔画像とあらかじめ登録しておいた様々な向き の顔画像との輝度に関する一致度に基づいて算出する。ただし, 最も近いと判定された顔の要素のみに 1 , 残りの要素には 0 が 割り当てられる.

ここで，学習者は環境中のいずれかの物体を必ず見ると仮定 すると, $\boldsymbol{\theta}^{g}$ はその $i$ 番目の要素が

$$
\tilde{\theta}_{i}^{g}= \begin{cases}\theta_{i}^{g} & \text { if } s_{i}>0 \\ 0 & \text { otherwise }\end{cases}
$$

であるような $N$ 次元べクトル $\tilde{\boldsymbol{\theta}}^{g}$ に修正される.ここで $s_{i}$ は 環境中の物体配置を表現する $N$ 次元べクトル $\boldsymbol{s}$ の $i$ 番目の要 素とし, $i$ 番目のスポットに物体が配置されていればその物体 の ID である $i d$, そうでなければ 0 が $i$ 番目の要素に設定され るとする，学習者は $s$ を観測可能であると仮定する.

\section{2 言葉による注意モジュール}

言葉による注意モジュールは, 養育者が発した物体のラベル についての観測情報を表す $L$ 次元べクトル $\boldsymbol{l}$ を入力として, 共 同注意のために注視されるべき物体を

$$
\boldsymbol{o}^{l}=\boldsymbol{W}^{l} \boldsymbol{l}
$$

のように出力する. ここで, $\boldsymbol{o}^{l}$ は, 養育者の発話を手がかりと したときに各物体が注視されるべき程度を要素とする $M$ 次元 ベクトルである，また $\boldsymbol{W}^{l}$ はマッピングのパラメータである $M \times L$ 行列である. 本論文の実験では, $\boldsymbol{l}$ として, 養育者の発 話とあらかじめ登録された単語との一致度を要素とするべクト ルを用いる。ただし, 最も近いと判定された単語の要素のみに

1 , 残りの要素には 0 が割り当てられるとする.

ここで, 養育者の発話を手がかりとしたときに環境中の各ス ポットが注視されるべき程度を要素とする $N$ 次元べクトル $\tilde{\boldsymbol{\theta}}^{l}$ 
は，その $i$ 番目の要素を

$$
\tilde{\theta}_{i}^{l}= \begin{cases}o_{s_{i}}^{l} & \text { if } s_{i}>0 \\ 0 & \text { otherwise }\end{cases}
$$

のように決定することで求められる.

\section{3 統合}

各注意モジュールの出力 $\tilde{\boldsymbol{\theta}}^{g}$ と $\tilde{\boldsymbol{\theta}}^{l}$ を統合して, 注視対象が 決定される. 決定には, 統合されたべクトル $\tilde{\boldsymbol{\theta}}=\tilde{\boldsymbol{\theta}}^{g}+\tilde{\boldsymbol{\theta}}^{l}$ を大 きさが 1 になるように正規化したものを用い，これを各スポッ トの確率として, 確率的に注視対象のスポットが選択される.

この確率的な選択により, $i$ 番目のスポットが選択されたと き, これに対応する $i$ 番目の要素が 1 , その他の要素が 0 と設 定される $N$ 次元べクトルを $\boldsymbol{\theta}$ と呼ぶ. またその結果 $j$ 番目の ID を持つ物体が注視されたとき, この物体に対応する $j$ 番目 の要素が 1 , その他の要素が 0 と設定される $M$ 次元ベクトル を $\boldsymbol{o}$ と呼ぶ。ここで $\boldsymbol{\theta}_{d}$ および $\boldsymbol{o}_{d}$ を, 養育者が注視している スポットおよびそのスポットにある物体の ID に対応する要素 が 1 ，その他の要素が 0 と設定される $N$ および $M$ 次元べク トルであるとすると, $\boldsymbol{\theta}=\boldsymbol{\theta}_{d}$ および, $\boldsymbol{o}=\boldsymbol{o}_{d}$ のとき, 共同注 意に成功したと見なされる, ただし, 学習者には共同注意が成 功したか否かの情報は与えられない．

\section{4 相互排他性原理に基づく学習則}

各試行において，学習者は観測情報 $\boldsymbol{g}$ 拉よび $\boldsymbol{l}$, そしてこれ らをもとに実行された注視 $\boldsymbol{\theta}$ とその結果観測された物体の情報 $\boldsymbol{o}$ をもとに, 各モジュールの学習を行う。ここで養育者の, 各 スポットの注視の仕方と各物体のラベルのつけ方がそれぞれ相 互排他的であると仮定する (Fig. 3 参照)。すなわち, 養育者 の注視の様子 $\boldsymbol{g}$ と注視しているスポット $\boldsymbol{\theta}_{d}$, および養育者の 発話したラベル $\boldsymbol{l}$ と注視している物体の ID $\boldsymbol{o}_{d}$ が, それぞれ 1 対 1 の対応関係を持っているとする。 このとき, 養育者と共 同注意を達成するため, 学習者はマッピングの結合荷重である $W^{g}$ および $W^{l}$ を変更することで, この対応関係を学習する必 要がある.

学習者が観測できる情報 $\boldsymbol{\theta}$ と $\boldsymbol{o}$ は, 養育者の注視を表す $\boldsymbol{\theta}_{d}$ と $\boldsymbol{o}_{d}$ とは必ずしも一致しない. しかし, 周囲の物体あるいは その位置が変化する状況の中で経験を積み重ねていくと, $\boldsymbol{g}$ と $\boldsymbol{l}$ が観測されたときに $\boldsymbol{\theta}$ と $\boldsymbol{o}$ が $\boldsymbol{\theta}_{d}$ と $\boldsymbol{o}_{d}$ に一致する傾向が

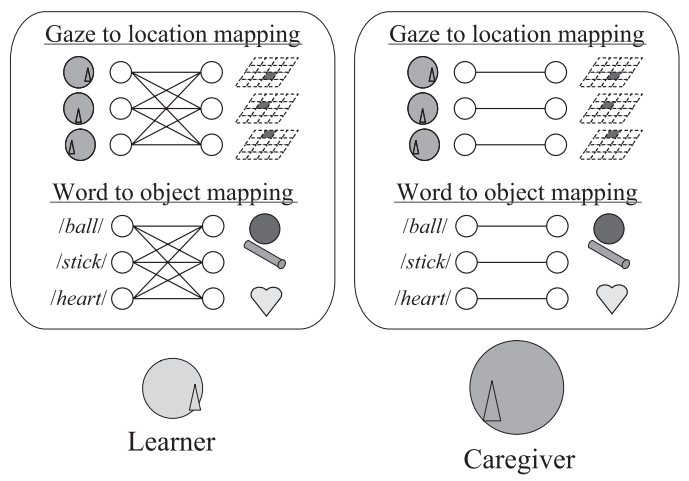

Fig. 3 Examples of initial mappings of the learner and mutually exclusive ones of the caregiver
高いという統計的性質を見出すことができる。これを利用して, ヘッブ学習のような統計的な対応を学習する手法により, 共同 注意のための視線追従 [6] [7] や語彙 [8] [9] のマッピングを学習 可能であることが先行研究で示されている. しかしこれらの先 行研究では, 学習すべき複数の対応関倸がそれぞれ相互排他的 なものであること，また共同注意に利用可能な注意モジュール としてそれらが相補的であることを利用できていなかった。

これに対し，対応関倸がどれだけ相互排他的に見えるかに応 じて，観測された対応関倸をマッピングに反映させる度合いを 調整する交差投錨型ヘッブ則が提案されている [13]. 本研究で はこれを修正した学習則をマルチモーダルな共同注意学習の問 題に適用することで, 過去の経験を利用することによる各モダ リティの学習の加速, および, モダリティ間の学習の相互促進 を実現する。

注視行動を行ったあと, 学習者は自身の注視経験に基づいて 各マッピングの結合荷重を更新する。視線追従と語氣のマッピ ングには同様の更新則が適用されるため, ここでは視線追従の マッピングを例として説明する．視線追従マッピングの入力 $\boldsymbol{g}$ とシステム全体の出力 $\boldsymbol{\theta}$ の最大值を持つ要素を, それぞれ勝者 $i^{*}$ と $j^{*}$ と呼ぶ. ここで $t$ ステップ目に, $\boldsymbol{\theta}$ により, いずれか の物体が注視されたとき, 視線マッピングの $i^{*}$ 番目の入力要素 と $j^{*}$ 番目の出力要素の間の結合荷重 $w_{i^{*} j^{*}}^{g}(t)$ は

$$
w_{i^{*} j^{*}}^{g}(t+1)=\mu_{g}\left(g_{i^{*}} \theta_{j^{*}}-w_{i^{*} j^{*}}^{g}(t)\right)
$$

のように更新される.ここで $\mu_{g}$ は現在の入出力関係の視線追従 マッピングにおける相互排他度を表す，すなわち，視線追従マッ ピングの結合荷重として, 現在の入出力関倸がどの程度相互排 他的なものとして表されているかを表す，本論文では収束值近 傍での学習の挙動がより安定になるように, 係数 $\mu_{g}$ を $g_{i^{*}} \theta_{j^{*}}$ ではなく, $\left(g_{i *} \theta_{j^{*}}-w_{i^{*} j^{*}}^{g}(t)\right)$ に掛ける形に交差投錨型ヘッブ 則 [13] を修正している. $\mu_{g}$ はマッピングの入力要素の排他度 $\eta_{i j}^{g}$ と出力要素の排他度 $\eta_{i j}^{\theta}$ の積 $\mu_{g}=\eta_{i^{*} j^{*}}^{g} \cdot \eta_{i^{*} j^{*}}^{\theta}$ として求め られる. 各入出力要素の排他度は

$$
\begin{aligned}
& \eta_{i j}^{g}=\exp \left(-\frac{\sum_{k, k \neq j} w_{i k}^{g}(t)}{\alpha^{2}}\right) \\
& \eta_{i j}^{\theta}=\exp \left(-\frac{\sum_{k, k \neq i} w_{k j}^{g}(t)}{\alpha^{2}}\right)
\end{aligned}
$$

と計算される。 ここで, $\alpha$ は相互排他性の逆感度を表すパラメー タである。したがって, 相互排他度 $\mu_{g}$ は入出力の勝者間が相 互に排他的であるほど大きくなる。つまり，式（5）の更新則で は, より相互排他的な関係にある入出力要素間の結合関係につ いては学習が進む一方, そうでない入出力要素間の結合関倸に ついてはあまり学習が進まないことにより，相互排他的なマッ ピングが構築されることが期待される.

同時に, 入力の勝者要素と出力の勝者以外の要素との結合荷 重, 拉よび出力の勝者要素と入力の勝者以外の要素との結合荷 重は側抑制によって

$$
\begin{aligned}
& w_{i j^{*}}^{g}(t+1)=w_{i j^{*}}^{g}(t)-\beta w_{i j^{*}}^{g}(t) \\
& w_{i^{*} j}^{g}(t+1)=w_{i^{*} j}^{g}(t)-\beta w_{i^{*} j}^{g}(t)
\end{aligned}
$$


のように減らされる。ここで $\beta$ は側抑制の強さを表すパラメー 夕である. 以上の学習則によって学習者は養育者のもつ相互排 他的なマッピングを学習する.

2.4.1 提案手法によるモジュール内の相互促進作用

提案手法はモジュール内の相互促進的学習を実現するように 設計されている. 式（5）の更新は入力・出力の勝者が他方の勝 者以外の要素との間に相互排他的な関係が見出されていないと き, 入力の勝者 - 出力の勝者との結合荷重が増やされやすい更 新則になっている。また式（8）および式（9）の側抑制によっ て相互排他的な関係が見出された入力の勝者と出力の勝者は勝

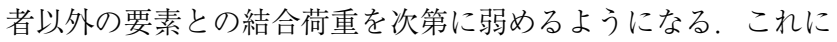
より, 提案手法はモジュール内の対応学習を加速する相互排他 性バイアスとして機能すると期待される。

2.4 .2 提案手法によるモジュール間の相互促進作用

提案手法はモジュール間の相互促進的学習も実現するように 設計されている，交差投鈿型ヘッブ則によって学習された結合 荷重は相互排他的な関係が発見されたときに大きな值となる。 学習者は共同注意を行う際, 各注意モジュールの出力を統合し, 統合された出力に従って物体を注視する。したがって，より相 互排他的な対応関係が学習された注意モジュールの出力が共同 注意の試行に利用されることとなり，他方の注意モジュールは， 相互排他的な関係の学習が進む前から，相互排他的な関係をよ り頻繁に経験できることになる。これより，提案手法はモジュー ル間の対応学習を促進する相互排他性バイアスとして機能する と期待される。

\section{3. 実験}

提案手法により，複数モジュールの学習がどのように相互促 進可能であるかを検証する。 まず実例として，比較的簡単な状 況における，実ロボットと人とのインタラクションを通じた共 同注意学習場面に提案手法を適用した結果について述べる。 そ の後，計算機シミュレーションを用い，提案手法によるモダリ ティ内拉よびモダリテイ間での相互促進効果について検証する 最後に, 親子インタラクションを模した状況での計算機シミュ レーション結果を示し, 幼児の発達過程との相同性について議 論する。

\section{1 実ロボットを用いたインタラクション実験}

本実験では子供型ヒューマノイドロボット $\mathrm{CB}^{2}$ (Child robot with Biomimetic Body）[14]を用いた．ロボットと教示者はテー ブルを挟んで互いに向かい合わせに座らせる（Fig. 4 参照），実 験では, 教示する物体の数を 3 とし, テーブルを右・中心・左に 3 等分し，各スポットに物体を配置する $(N=3, M=3)$ 。一 度に置かれる物体の数は 2 とし, 3 個の物体の中からランダム に選択したものを，テーブルのいずれかの位置に重複しないよ うに配置する $\left(M_{o}=2\right)$. 配置する物体とその位置は 5 ステッ プごとに入れ替えられる $(T=5)$ ，ロボットのタスクは，共同 注意ができるように，ロボットから見て右・中心・左に向いて いる教示者の顔画像を，それぞれ右・中心・左のスポットに対 応付けること，およびそれぞれの物体とそれらに固有なラベル を対応付けることである。ここでロボットは共同注意が成功し たかどうかを直接知ることができないため，その是非にかかわ

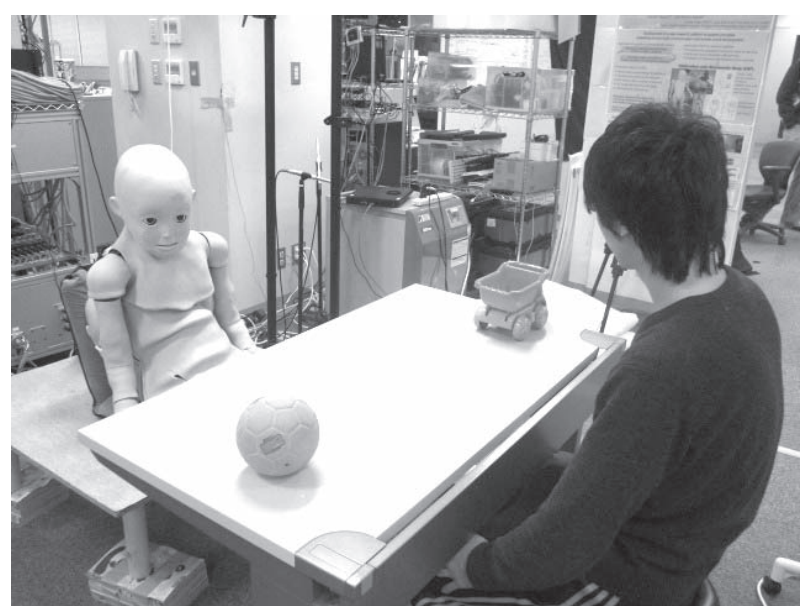

Fig. 4 A sample scene of human-robot interaction of joint attention

Table 1 Success rates of face and object recognition

\begin{tabular}{|c|c|c|c|}
\hline $\begin{array}{c}\text { Gaze } \\
\text { direction }\end{array}$ & $\begin{array}{c}\text { Face recognition } \\
\text { rate }(\%)\end{array}$ & $\begin{array}{c}\text { Object's } \\
\text { label }\end{array}$ & $\begin{array}{c}\text { Object recognition } \\
\text { rate }(\%)\end{array}$ \\
\hline right & 100 & car & 100 \\
center & 97.5 & ball & 98.1 \\
left & 88.2 & bat & 98.4 \\
\hline
\end{tabular}

らず，注視した物体をもとに各注意モジュールの結合荷重を更 新することに注意されたい。

視線による注視モジュールの入力として $\boldsymbol{g}$ に眼球の方向では なく顔の方向を用いる，高い精度で視線を捉えるためには，眼 球の方向についても考慮することが望ましい. しかし，幼児の 知見 [1] からも顔の方向は人の注視方向を知る有効な手がかり の一つであることが知られており, 本研究では簡単のため顔の 方向についての観測から $\boldsymbol{g}$ を求める. 具体的には, 観測された 画像に対してあらかじめ登録された様々な向きの顔画像の輝度 值のテンプレートマッチングを行い，各顔画像の最大の相関值 を一致度として $\boldsymbol{g}$ を求めた。 また同様に, 観測された画像に対 してあらかじめ登録された物体画像の色差ヒストグラムのテン プレートマッチングを行い, 各画像の最大の相関值の最も高い 值をもつものから物体の ID を求めた。顔認識成功率抢よび物 体認識成功率を Table 1 に示す。それぞれの平均值は $95.2 \%$, $98.8 \%$ でった。言葉についての入力ベクトル $\boldsymbol{l}$ は沉用大語彙 連続音声認識エンジン Julius を用いて求めた，教示者は物体の ラベルのみを発話することとしたため, 本実験での音声認識成 功率は $100 \%$ であった，物体の配置の方法については，ランダ ム性を保持するようシステムに決定させた，この配置について は画像処理で特定可能であるが，本実験では簡単のためロボッ 卜に直接教示した. 更新則のパラメータは経験的に $\alpha=1.2$, $\beta=0.5$ とした

Fig. 5 (a) は, 50 ステップのインタラクション実験を 5 回 行った際の, 直近の過去 10 ステップの共同注意成功率の平均 值の遷移を示している. また Fig. 5 (b) は, そのときの視線追 従抢よび語彙のマッピングの習熟率の遷移を示している，習熟 率とは，そのマッピングを用いて，正しい注視位置が選択され る確率の平均值のことであり, 各時点でのマッピングに対して, 


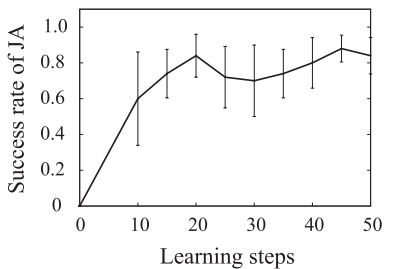

(a) Success rate of joint attention

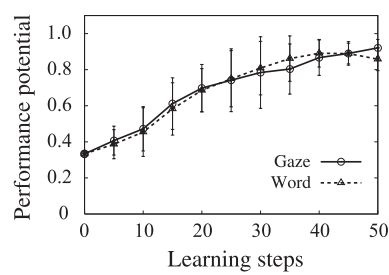

(b) Performance potential of each mapping
Fig. 5 Learning progresses in human-robot interaction

起こりうるすべての場合の $\boldsymbol{g}$ と $\boldsymbol{l}$ を入力し, 正しい選択がなさ れる確率を計算することで求めた. Fig. 5 (a) から, 共同注意の 成功率は 20 ステップあたりでおよそ $80 \%$ に達しており, また Fig. 5 (b) から各マッピングの習熟率は 30 ステップあたりでお よそ $80 \%$ に達していることが分かる。ここではパラメー夕 $\alpha$, $\beta$ を固定して実験を実施したが, $\alpha=[0.3,1.6], \quad \beta=[0.3,0.6]$ の範囲で同様の学習が可能であることをこの実験設定を再現し た計算機シミュレーションにより確認している.

本インタラクション実験において 1 ステップの所要時間は $20[\mathrm{~s}]$ くらいであったため, 10 分程度という早い時間で, 人の 右・中心・左の視線方向拉よび三つの対象物の名前を理解して共 同注意が可能であるといえる。 また，入力べクトルの認識率は $100 \%$ はななかったが，学習は可能であった，認識率の低さがど のように影響するかについては，次節でより詳しく検討する。

\section{2 計算機シミュレーションによる相互促進効果の検証}

前節での実例のように，実環境において養育者の言葉や視線 を常に $100 \%$ 認識することは難しい。認識にエラーを含む場合, 統計的な対応関係を発見し, 学習することはさらに難しくなる. これに対し, 提案手法はモジュール内相互促進とモジュール間相 互促進によって, 認識エラーを含む状況に打いてもより効率的 な学習が可能であることが期待される。 そこで人工的に入力の 認識にエラーを導入した計算機シミュレーションを実施し，そ の効果を検証する。 具体的には, 入力の認識率 $p_{r}$ と呼ぶ確率 を定め, 確率 $p_{r}$ で正しいべクトルが, 確率 $1-p_{r}$ で誤ったべ クトルが入力される，という形の認識エラーを導入する。 ここ で, 元々の入力ベクトルに近いものとの誤認識が起りやすいと し, 具体的には, 入力ベクトルが正しく認識された際に選択さ れるべき要素の ID を中心とするガウス分布に従って, 選択さ れる入力の勝者要素を決定した. 認識率は, ガウス分布の分散 を変えることで調整した。

上記の認識エラーを導入した共同注意学習の計算機シミュレー ションにおいて，次節ではまず単一のモジュールを用いた共同 注意学習を想定し, 視線による共同注意に対して相互排他性原 理に基づく学習則を適用した場合のパフォーマンスを, 相関学 習の方法の一つであるヘッブ学習のそれと比較することで，モ ジュール内の相互促進効果を検証する. 次に視線および言葉によ る注意モジュールを用いたマルチモーダルな共同注意を想定し， 提案手法による学習とヘッブ学習の比較をすることでモジュー ル間の相互促進効果を検証する。比較対象のヘッブ学習では, 視 線追従マッピングの結合を

$$
w_{i, j}^{g}(t+1)=w_{i, j}^{g}(t)+\gamma\left(g_{i} \cdot \theta_{j}-w_{i, j}^{g}(t)\right)
$$

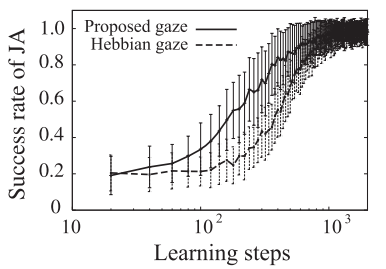

(a) Success rate where the recognition rate is set to 1.0

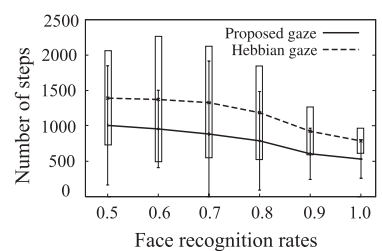

(b) Necessary steps to reach a certain success rate of joint attention with respect to recognition rate
Fig. 6 Comparison of learning results with single module between the proposed method and Hebbian learning

のように更新させた，語彙マッピングの結合荷重更新も同様と した。ここで $\gamma$ は学習率である.

\subsection{1 モジュール内での相互促進効果}

認識率 $p_{r}$ を 0.5 から 1.0 まで 0.1 ずつ変化させたそれぞれ の場合について， 2,000 ステップのインタラクションを通じて 視線による共同注意モジュールを学習させるシミュレーション を50 回実施した。ただし、インタラクションのパラメータを $N=10, M=10, M_{o}=5$ とした. 提案手法とへッブ学習の 各パラメー夕は経験的に $\alpha=0.8, \beta=0.05, \gamma=0.01$ とした.

Fig. 6 (a) に, 認識率を $p_{r}=1.0$ に固定した際の, 直近の 過去 20 ステップの共同注意成功率の遷移を示す. ヘッブ学習 (Hebbian gaze：破線）に比へ，提案手法 (Proposed gaze：実 線）の学習が速いことが分かる. Fig. 6 (b) は，直近の過去 100 ステップの共同注意成功率が, 認識率が変えられた各状況に招 いてある程度よいパフォーマンスであると考えられる成功率を $1 \%$ 水準で有意に上回るのに要したステップ数の平均值を示した ものである。ここで，ある程度よいパフォーマンスの基準とな る成功率として, 正しいマッピングをシステムに与えて共同注 意を試みさせたときの成功率の $80 \%$ の確率を用いた，分散は大 きいが, ヘッブ学習（Hebbian gaze：破線）に比べ, 提案手法 (Proposed gaze: 実線) のほうが認識率が低い場合においても, 早くなっていることが分かる. したがって, モダリテイ内の相互 促進が実現されているといえる。ここではパラメータ $\alpha, \beta, \gamma$ を固定して実験を実施したが， $p_{r}=1.0$ のとき， $\alpha=[0.6,1.2]$, $\beta=[0.01,0.1], \gamma=[0.01,0.1]$ の範囲で同様の学習が可能であ ることを確認している.

\subsection{2 モジュール間での相互促進効果}

視線と言葉による共同注意モジュールの両方を用い，前節と 同様に認識率 $p_{r}$ を変えて $, 2,000$ ステップのインタラクショ ンを通じて，これらの共同注意モジュールを学習させるシミュ レーションを 50 回実施した。 ただし，インタラクションのパ ラメータを $N=10, M=10, M_{o}=5$ とした，また，学習の パラメー夕は経験的に $\alpha=1.2, \beta=0.5, \gamma=0.05$ とした.

Fig. 7 (a) に視線およびラベルの認識率を 1.0 に固定して, 直 近の過去 20 ステップの共同注意成功率の遷移を示す. ヘッブ学 習 (Hebbian multi: 破線) に比心，提案手法 (Proposed multi: 実線）の学習が速いことが分かる. Fig. 7 (b) は, Fig. 6 (b) と同 様に, 直近の過去 100 ステップの共同注意成功率が有意にある程 度よくなるのに要したステップ数の平均值を示したものである. 


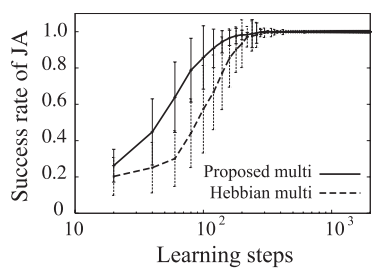

(a) Success rate where the recognition rate is set to 1.0

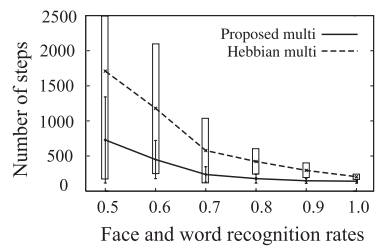

(b) Necessary steps to reach a certain success rate of joint attention with respect to recognition rate

Fig. 7 Comparison of success rate of joint attention with gazedriven and word-driven modules between the proposed method and a Hebbian learning where the recognition rate is set to 1.0

ここで比較のため, ある程度よいパフォーマンスの基準となる成 功率として, Fig. 6 の描画の際に用いた值を用いた。ヘッブ学習 (Hebbian multi : 破線) に比べ, 提案手法 (Proposed multi : 実線）の学習が速いことが分かる. Fig. 6 (b) と Fig. 7 (b) を比 較すると，視線のみを利用した単一モジュールの共同注意シス テムより, マルチモジュールの共同注意システムのほうの学習 が速く，分散も小さいことが分かる。これは早期に学習できた 側のマッピングを共同注意の試行に利用することによる，促進 効果であるといえる.

そこで，それぞれのモダリテイの認識率が異なる状況を設定 し, 提案手法の促進効果をより詳細に検証した. Fig. 8 に視線と ラベルの認識率をそれぞれ独立に変更したシミュレーションの結 果を示す。ただし，提案手法については Fig.8 (a), (c), (e)に, ヘッブ学習については Fig. 8 (b), (d), (f) に示した. Fig.8 (a) と (b) は, 直近の過去 100 ステップの共同注意成功率が有意に ある程度よくなるのに要したステップ数の平均值を色の薄さで 示している。ここで, ある程度よいパフォーマンスの成功率と して，正しい視線抢よびラベルのマッピングをシステムに与え て共同注意を試みさせたときの成功率の $80 \%$ の確率を用いた。 視線とラベルの認識率が比較的低い場合は特に顕著に, 提案手 法のほうがある程度よいパフォーマンスに達するのが早いとい える。また Fig. 8 (c) と (d) は視線のマッピングの, Fig. 8 (e) と (f) はラベルのマッピングの習熟率が, 同じ基準の確率を有意 に上回るのに要するステップ数を色の薄さで示している．視線 追従のマッピングについて比較すると, ヘッブ学習（Fig. 8(d)) では，ラベルの認識率が低い場合に，習熟率の向上が遅いのに 対し, 提案手法 (Fig. 8 (c)) では, 比較的早くなっていること が分かる。一方ラベルのマッピングを比較すると，ヘッブ学習 （Fig. 8(f)）では視線の認識率が低い場合に習熟率の向上が遅い のに対し, 提案手法 (Fig. 8 (e)) では比較的早くなっているこ とが分かる。これらの結果は，より早期に相互排他性が向上し た側のマッピングが共同注意の試行に利用されるため，他方が 認識率が低くくても，相互排他性を向上させることができてい ることを示して抢り，提案手法によるモジュール間の相互促進 が実現できているといえる。ここではパラメータ $\alpha, \beta, \gamma$ を 固定して実験を実施したが， $p_{r}=1.0$ のとき， $\alpha, \beta$ がそれぞ れ 1.0 以上, $\gamma=[0.01,0.3]$ の範囲で同様の学習が可能である

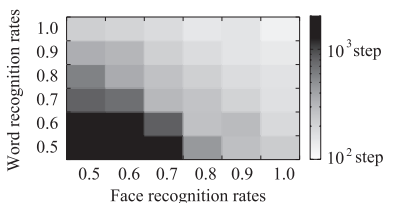

(a) Success rate of JA by CA-Hebb

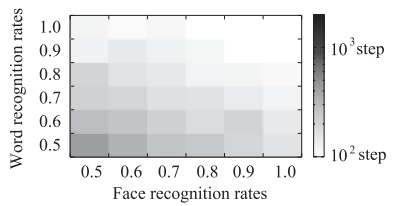

(c) Performance potential of gaze by CA-Hebb

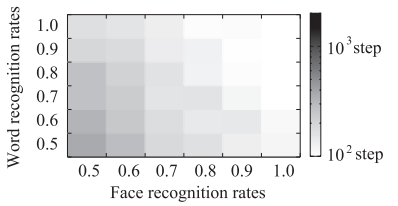

(e) Performance potential of word by CA-Hebb

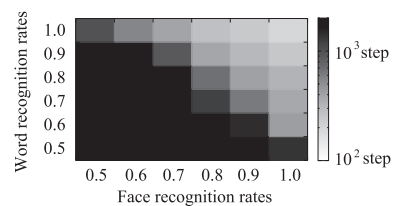

(b) Success rate of JA by Hebb

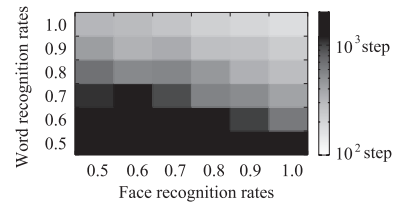

(d) Performance potential of gaze by $\mathrm{Hebb}$

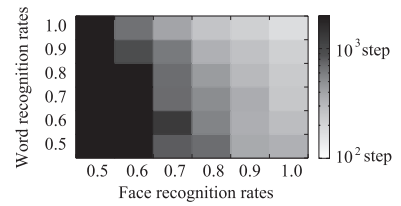

(f) Performance potential of word by Hebb
Fig. 8 Comparison of necessary steps to reach a certain level of learning performance between the proposed method (CA-Hebb: (a), (c), (e)) and a Hebbian learning (Hebb: (b), (d), (f)) under different pairs of recognition rates: success rates of joint attention (a) and (b), performance potential (c) and (d) of gaze-driven module, and performance potential of word-driven module

\section{ことを確認している}

\section{3 検証 2 ：養育者を考慮した学習過程}

最後に親子インタラクションを模した状況での計算機シミュ レーションを実施し, 幼児の発達過程をどの程度再現できるかに ついて検討した. 幼児は 18 ケあたりでは, 最大で 200 語, 平 均 100 語のラベルを発話できる $[2]$ とされている. そこで本節で は，提示する物体の数をこれと同程度の数に合わせ， $M=200$ とした計算機シミュレーションを実施する. 環境の分割数は教 示される物体の数に比へ， かなり小さいと考え， $N=10$ とし た。ここで幼児が獲得するラベルの中には聞き取りやすいもの とそうでないものが含まれており，また遠くの領域の異なる位 置を見ている養育者の顔の違いは小さいのに対し，近くのそれ は比較的大きいと考えられる。そこでこれらの違いを認識率の 違いと考え, 計算機シミュレーションでは各モダリティの入力 を二つのグループに分けた，具体的には認識の容易な要素（近 くの視線打よび簡単な言葉）の認識率を 1.0 , 認識の難しい要 素（遠くの視線抢よび難しい言葉）の認識率を 0.7 とし, 各グ ループの要素数は近くの視線を 5 , 遠くの視線を 5 , 簡単な言 葉を 10 抢よび難しい言葉を 190 とした。

実際の親子インタラクションでは, 養育者は "Learning from Easy Mission” [15] と呼ばれるような学習者の学習を促進させ る，学習者に配慮した行動を行うと期待される。そこで本節の シミュレーションでは, 養育者は学習者の語彙理解の能力に配 慮して振る舞うとする. 具体的には, 学習者がそのラベルを知っ ているように見える物体を優先的に選択させるように，幼児が 


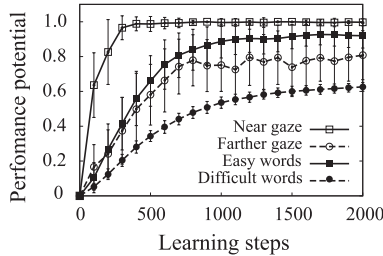

(a) Performance potentials

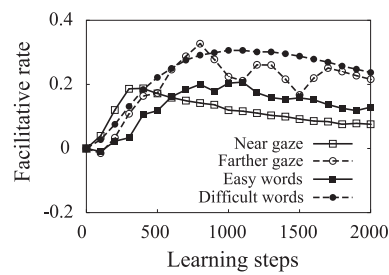

(b) Facilitative rates
Fig. 9 Learning progress under the resembled mother-infant interaction: (a) performance potentials of near- and further-gaze as well as easy- and difficult-word mappings and (b) facilitative rates of them

5 回連続で共同注意を成功させた物体があれば, これを選択さ せることとした，また学習者がラべルを知っているように見え る物体がない場合には，近い場所にありかつ簡単なラベルの物 体を優先して選択させるとする。しかし，学習が進むと遠くに も学習者が知っている物体が存在する場面が増えていくため, 養育者は遠い領域でのインタラクションを増やしていくことに なる。

上記の設定で 2,000 ステップの共同注意学習シミュレーショ ンを 50 回実施した。学習のパラメータは 3.2 .2 節と同様に $\alpha=1.2, \beta=0.5$ とした. Fig. 9 (a) に, 視線追従抢よび語彙 のマッピングの習熟率の平均値の遷移を 100 ステップごとに示 す，拉よそ 300 ステップあたりで近くの視線追従 (Near gaze: 口の実線）ができるようになり，遅れておよそ 800 ステップあ たりで遠くの視線追従（Farther gaze：○の破線）ができるよう になるという学習過程が現れた。これは学習者が言葉の注意モ ジュールを利用し, 遠くの場所にある知っているラベルの物体 を注視することで, 視線追従の学習が促進できたためであると いえる，一方幼児の共同注意は，12ケ月ごろには，幼児自身の視 野内にある近くの物体に対するもの限られるのに対し，18ケ月 ごろでは目の前に物体がない場合にも視野外の遠くの物体を探 しあて, 共同注意ができるようになること $[1]$ が知られており, 本節のシミュレーションの結果に一定の相同性が認められる。

Fig. 9 (b) に視線追従抢よび語彙のマッピングの習熟率の促進 度の遷移を 100 ステップごとに示す。ここで促進度とはマルチ モーダルな共同注意学習システムのマッピングの習熟率と単一 モダリテイのみを利用した共同注意学習システムのマッピング の習熟率との差とした. Fig. 9 (b) から難しい言葉の語彙マッピ ングの学習の促進度 (Difficult words：の破線）が比較的大 きくなり始めるのは 300 ステップを越えたあたりからであるこ とが分かる.ここでFig. 9 (a) を見ると，その 300 ステップあ たりはちょうど近くの視線追従 (Near gaze: $\square$ の実線) が獲得 できたころであり，言葉としては簡単な言葉（Easy words の実線）を 4 割, 難しい言葉（Difficult words：の破線）を 2 割覚え, 合わせて 40 語程度をようやく覚えたころである。こ のことから, 遠くの視線追従 (Farther gaze：○の破線）が未 熟な段階からも近くの視線追従（Near gaze： $\square$ の実線）を語 彙の学習に利用でき始めていることが分かる。 また Fig. 9 (b) から， 1,000 ステップあたりで両方の語彙マッピング学習の促 進度 (Easy words 実線，および Difficult words
破線）は最大となることが分かる。これは Fig. 9(a)を見ると， 学習できた遠くの視線追従（Farther gaze：○の破線）を十分に 利用できるようになったころに対応しているようであり，言葉 としては簡単な言葉を 9 割, 難しい言葉を 5 割覚え, 合わせて 100 語程度覚えたころに対応するようである。，一方幼児は，平 均的に 100 語程度を獲得する 18 ケごろ [2]に, 物体のラベル の学習に親の視線情報を利用できるようになることが知られて いる [3]. このような乳児の振る舞いと, 本シミュレーションに おいてある程度の語数を覚えるころと視線によるラベルマッピ ングの学習の促進度が最大になるころが同時期であったことに 一定の相同性が認められ, 興味深い. しかし本シミュレーショ ンは特定のパラメータのみを扱う限定的なものであるため, 定 量的な一致までを議論することは困難であり, パラメータの妥 当性などについてのより詳細な検証が今後の課題となる.

\section{4. おわりに}

本研究では視線追従拉よび言葉によるマルチモーダル共同注 意の同時学習に抏いて, 相互排他性バイアスを利用する学習シ ステムを提案した。実ロボットを用いた人とのインタラクショ ン実験抢よび計算機シミュレーションに提案手法を適用し, 各 モダリティの共同注意の機能の学習に抒いて，モダリテイ内㧍 よびモダリテイ間での相互促進効果を確認した。

これまでにも複数モジュールを同時学習させることにより複 雑な対象を効率的に学習させる研究が行われてきた $[16] 〜[20]$. MOSAIC [16] や階層混合モデル [17], RNN エキスパート混合 モデル [18] 等の分割統治型の複数モジュール学習の手法では, 状態空間を分割し，各モジュールにそれぞれを分担させること で, 効率的な学習を実現している. これに対し提案手法では, こ のような分担については議論せず，視線やラベルといった異なる モダリテイの情報に基づく複数のモジュールの競合的な統合を 通じて, いかに学習を相互促進的に進めさせられるかに注目し ている点で異なる。一方 Uchibe ら [19] は構造の異なる複数の 強化学習モジュールの競合的な同時学習において, 性能は高く ないが学習の速いモジュールを用いたときの経験も学習に利用 することで, 性能は高いが学習の遅いモジュールを実時間で学 習させられることを示した，提案手法も，視線および言葉を利用 したマルチモーダルな共同注意の学習に打いて, 早期に性能が よくなった部分を双方に利用し合うことで効率的な学習を実現 できている点では同じである，ただし，提案手法は 1 対 1 マッ ピングの構築に特化したものであるという点と, これに有効な 相互排他性バイアスを積極的に利用することで，モダリテイ間 のみならずモダリテイ内に扔いても相互促進的学習を実現した ものであるという点で異なると考えられる。 また Sugita ら [20] は, 動作の系列と言葉の系列を学習するリカレントニューラル ネットワークをそれぞれの PB 值と呼ばれる変数を共有させる ことで結合したネットワークを提案し, 特定の行動についての教 師あり学習により，これらの系列の汎化が可能であることを示 した.この研究は異なるモジュールの学習を別のモジュールの学 習に利用するという点で本研究と同じであるが, Sugita ら [20] はこれを沉化に利用したのに対し, 提案手法は双方の学習の相 互促進に利用しているという点, またその結果, 厳密に教師信 
号が与えられなくても学習を可能にしている点で異なると考え られる. しかし, 提案手法はこれらの従来研究と排他的ではな く，これらと融合させることが今後の一つの課題である.

また親子インタラクションを模した状況に拀いて提案手法 が, Butterworth ら [1] の示す視線追従の段階的発達過程掞よ び Baldwin [3] の示す 18ケ月児の視線情報を利用した語彙学習 と対応する発達過程を再現可能であることを示した。本稿では 一組のパラメータによる計算機シミュレーションの結果につい てのみ議論したが, これらのパラメータの妥当性を検証すると ともに，これらを変動させた場合に提案手法が幼児の発達のバ リエーションをどの程度再現できるかを検討する必要がある。

人の幼児は, 共同注意学習を始める以前に, 視線追従マッピ ングの学習に必要な養育者の顔の認識 [21] や注視方向を向くた めの首振り運動 [22], および語裹マッピングの学習に必要な養 育者の発話するラベルの認識 [23] や物体の認識 [24] 等の能力を ある程度獲得しているということが発達心理学の研究で知られ ている，ただし，我々はこれらの能力は未熟であると考え，本 論文の実験では視線掞よびラベルといった入力の認識にエラー を導入し，このようなエラーに対する提案手法の有効性を確認 した．実験では入力についてのエラーのみしか考慮しなかった が, 各モジュールの出力值の処理に必要となる物体の認識抢よ び首振り運動の能力についてのエラーも今後考慮していく必要 がある。

しかし，本論文の実験では入力の認識にエラーがあることを 想定していたものの, その程度については一定であるとみなし ていた。一方，人の幼児を見ていると，言葉を覚え始める14ケ 月ごろから音節認識が語彙学習に特化したものに変わっていく こと [25] や言葉を 100 語覚える時期の前後で物体のカテゴリ 化の能力が変化すること [26] が示唆されており, 幼児は共同注 意を発達させていく中で共同注意に必要なこれらの離散化にか かる処理の能力を発達させると考えられる. しかし, 入力をど の程度正確に離散化できるか, また離散的なマッピングの出力 をどの程度正確に行動に反映させられるかは，どのようなマッ ピングを学習すべきか，に相互に依存するため，マッピングと 離散化は同時並行的に学習されることが望ましい，本論文では 入力の認識エラーに対し, 過去の経験や他のモダリティを積極 的に利用することにより，認識率の低さがある程度許容される ことを実験的に見た．したがって，提案手法に基づく方法では， 離散化の学習と並行したマッピングの学習が可能であることが 期待され，これを実現することが今後の課題となる。このよう に，モデルを段階的に洗練していくことが，人の発達を支える 学習メカニズムを解き明かすための有効なアプローチであると 考える.

\section{参 考 文 献}

[1] G. Butterworth and N. Jarrett: "What minds have in common is space: Spatial mechamisms serving joint visual attention in infancy," British Journal of Developmental Psychology, vol.9, no.1, pp.55-72, 1991.

[2 $]$ E. Bates, P.S. Dale and D. Thal: 'Individual differences and their implications for theories of language development,' The handbook of child language. pp.96-151, Wiley-Blackwell, 1995.
[3] D.A. Baldwin: "Infants' contribution to the achievement of joint reference," Child Development, vol.62, no.5, pp.875-890, 1991.

[ 4 ] P.E. Spencer: "Looking Without Listening: Is Audition a Prerequisite for Normal Development of Visual Attention During Infancy?," Journal of Deaf Studies and Deaf Education, vol.5, no.4, pp.291-302, 2000.

[5] M. Asada, K.F. MacDorman, H. Ishiguro and Y. Kuniyoshi: "Cognitive developmental robotics as a new paradigm for the design of humanoid robots," Robotics and Autonomous Systems, vol.37, pp.185-193, 2001.

[6] Y. Nagai, K. Hosoda, A. Morita and M. Asada: "A constructive model for the development of joint attention," Connection Science, vol.15, no.4, pp.211-229, 2003.

[ 7 ] C. Teuscher and J. Triesch: "To each his own: The caregiver's role in a computational model of gaze following," Nuerocomputing, vol.70, no.13-15, pp.2166-2180, 2007.

[8] D.K. Roy and A.P. Pentland: "Learning words from sights and sounds: a computational model," Cognitive Science, vol.26, no.1, pp.113-146, 2002.

[9] C. Yu: "The emergence of links between lexical acquisition and object categorization: a computational study," Connection Science, vol.17, no.3, pp.381-397, 2005.

[10] 菊池, 荻野, 浅田：“顕著性に基づくロボットの能動的語彙獲得”, 日 本ロボット学会誌, vol.26, no.3, pp.261-270, 2008.

[11] C. Yu, D.H. Ballard and R.N. Aslin: "The Role of Embodied Intention in Early Lexical Acquisition," Cognitive Science, vol.29, no.6, pp.961-1005, 2005.

[12] E.M. Markman and G.F. Wachtel: "Children's use of mutual exclusivity to constrain the meanings of words," Cognitive Psychology, vol.20, no.2, pp.121-157, 1988.

[13] Y. Yoshikawa, K. Hosoda and M. Asada: "Unique association between self-occlusion and double-touching towards binding vision and touch," Neurocomputing, vol.70, no.13-15, pp.22342244,2007

[14] T. Minato, Y. Yoshikawa, T. Noda, S. Ikemoto, H. Ishiguro and M. Asada: "CB2: Child robot with Biomimetic Body for Cognitive Developmental robotics," Procceeding of IEEE-RAS International Conference on Humanoid Robots, 2007.

[15] M. Asada, S. Noda, S. Tawaratsumida and K. Hosoda: "Visionbased reinforcement learning for purposive behavior acquisition," Procceeding of IEEE International Conference on Robotics and Automation, pp.146-153, 1995.

[16] D.M. Wolpert and M. Kawato: "Multiple paired forward and inverse models for motor control," Neural Networks, vol.11, no.7-8, pp.1317-1329, 1998.

[17] M.I. Jordan and R.A. Jacobs: "Hierarchical Mixtures of Experts and the EM Algorithm," Neural Computation, vol.6, no.2, pp.181-214, 1994.

[18] J. Tani and S. Nolfi: "Learning to perceive the world as articulated: an approach for hierarchical learning in sensorymotor systems," Neural Networks, vol.12, no.7-8, pp.11311141,1999

[19] E. Uchibe and K. Doya: "Competitive-Cooperative-Concurrent Reinforcement Learning with Importance Sampling," Procceeding of International Conference on Simulation of Adaptive Behavior: From Animals and Animates, pp.287-296, 2004.

[20] Y. Sugita and J. Tani: "Learning semantic combinatoriality from the interaction between linguistic and behavioral processes.," Adaptive Behavior, vol.13, no.1, pp.33-52, 2005.

[21] T. Farroni, S. Massaccesi, E. Menon and M.H. Johnson: "Direct gaze modulates face recognition in young infants," Cognition, vol.102, no.3, pp.396-404, 2007.

[22] C.V. Hofsten: "An action perspective on motor development," TRENDS in Cognitive Sciences, vol.8, no.6, pp.266-272, 2004.

[23] J.R. Saffran, R.N. Aslin and E.L. Newport: "Statistical learning by 8-month-old infants," Science, vol.274, no.5294, p.1926, 
1996.

[24] B. Younger and L. Cohen: "Infant Perception of Correlations among Attributes," Child Development, vol.54, pp.858-867, 1983.

[25] C.L. Steger and J.F. Werker: "Infants listen for more phonetic detail in speech perception than in word-learning tasks," Nature, vol.388, no.6640, pp.381-382, 1997.

[26] L. Smith: "Learnig to Recognize Objects," Psychological Science, vol.14, no.3, pp.244-250, 2003.

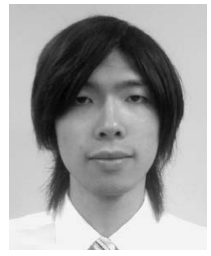

中野 吏 (Tsukasa Nakano)

2009 年大阪大学大学院工学研究科知能 $\cdot$ 機能創成 工学専攻博士前期課程修了. 同年同博士後期課程に 入学し現在に至る. 認知発達ロボティクスの研究に 従事.

（日本ロボット学会学生会員）

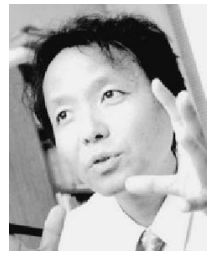

\section{浅田 稔 (Minoru Asada)}

1982 年大阪大学大学院基礎工学研究科物理系専攻 修了．工学博士．同年大阪大学基礎工学部制御工学 部助手. 1989 年同大学工学部電子制御機械工学科 助教授. 1995 年同教授. 1997 年同大学大学院工学 研究科知能・機能創成工学専攻教授となり現在に至 る。この間， 1986 年から 1 年間米国メリーランド 大学客員研究員. 知能ロボットの研究に従事. 1989 年情報処理学会研 究賞, 1992 年 IEEE/RSJ IROS'92 Best Paper Award 受賞. 1996 年日本ロボット学会論文賞受賞. 2001 年文部科学大臣賞 科学技術普 及啓発功績者の表彰、ロボカップ国際委員会会長. 阪大 FRC ロボ カップヒューマノイド研究プロジェクトリーダー。電子情報通信学 会, 情報処理学会, 人工知能学会, 日本機械学会, 計測自動制御学会, システム制御情報学会, IEEE R\&A, CS, SMC societies などの会 員.

（日本ロボット学会正会員）

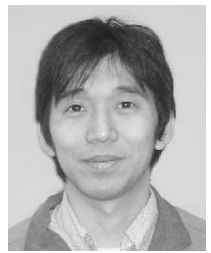

吉川雄一郎（Yuichiro Yoshikawa）

2005 年大阪大学大学院工学研究科知能 $\cdot$ 機能創成工 学専攻修了. 博士 (工学). 同年 ATR 知能ロボティ クス研究所研究員. 2006 年より JST ERATO 浅 田共創知能プロジェクト研究員となり現在に至る. 認知発達ロボティクスの研究に従事.

（日本ロボット学会正会員）

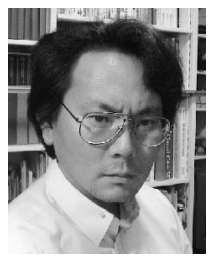

石黒 浩 (Hiroshi Ishiguro)

1991 年大阪大学大学院基礎工学研究科物理系専攻 修了．工学博士．同年山梨大学工学部情報工学科助 手. 1992 年大阪大学基礎工学部システム工学科助 手. 1994 年京都大学大学院工学研究科情報工学専 攻助教授, 1998 年同大学大学院情報学研究科社会 情報学専攻助教授。この間，1998 年より 1 年間, カリフォルニア大学サンディエゴ校客員研究員. 2000 年和歌山大学シ ステム工学部情報通信システム学科助教授. 2001 年より同大学教授. 1999 年より, ATR 知能映像研究所客員研究員. 現在, 大阪大学大学 院工学研究科知能・機能創成工学専攻教授および ATR 知能ロボティク ス研究所客員室長. 知能ロボット, アンドロイドロボット, 知覚情報基 盤の研究に興味をもつ. 人工知能学会, 電子情報通信学会, 情報処理 学会, IEEE, AAAI, ACM などの会員。（日本ロボット学会正会員） 